\title{
農業トラクタの長時間連続運転時にみられた 心身反応の例
}

\author{
○酒井一博, 川上间(労的科学研究所)
}

Physio-psychological Responses during Longterm Driving on Agricultural Tractor Kazuhiro Sakai, Tuyoshi Kawakani(Institute for Science of Labour)

\section{1 . 目的}

徐々に大型化・自動化の方向に進む宸業生産技 術体系をそこで钩く人間の側から評価する方法の 開発を目的とする。自動化・大型化する農業生産 技術体系のもとでの作業は、㖘作業者かオイレー 夕化し、マニュアル通りの操作を強いられたり、

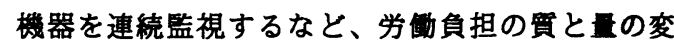

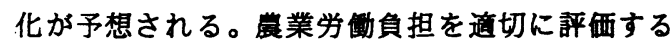
方法を改めて開発することによって、人間と機械 システムの共生に必要な人間工学的な設計基泮に ついて検討する基礎資料を得る。

\section{2. 方法}

1996年10月下旬に甬場にて、宸業トラクターに よる耕耘作業中のオヘレータの複合生理反応を連 続同時計测した。実験では高速条件 $(0.75 \mathrm{~m} / \mathrm{s}$ 、副 変速2、主変速2、クリープ入り、PT02速）と、低 速条件 $(0.38 \mathrm{~m} / \mathrm{s}$ 、副変速 3 、主変速 4 、クリープ入 り、PT01速) でそれそれ約 0.5 ha $(195 \times 25 \mathrm{~m})$ の耕 耘作業を行った。計測項目は、生体反応として眼 球運動（上下方向、左右方向）、心電図、筋電図 （右総指伸筋、左右僧帽筋、右大腿部四頭筋）、 呼吸数の 8 チャンネルをテレメータ方式で連続同 時記録した。このほかマシンパフォーマンスとし て、エンジン回転、車速、ハンドル操拕角なとも 生体反応テータと同時計測した。また、ビテォカ メラにてオヘレータの表情や姿勢などを撮影する とともに、観察法により作業経過のタイムスタテ イを行い分析の便に供した。とくに、タイムスタ ティでは耕耘中に起こる後向き動作のほか、あく ひなとの副次動作の出現を計数した。さらに、作 業速度、耕耘幅、環境条件なとの测定も行った。 被験者は33歳の男性（174cm、78kg）1名であった。

\section{3.主要な結果}

図1に、低速条件の実験で得られた各生理指標の 1 分値または 10 秒値の変動経過、困2には、各生理 指標の5分間の平均値の変動を示し、上段が低速条 件、下段が高速条件である。主要な結果は次の通 りであった。

1. 約 $0.5 \mathrm{ha}$ の䌊耕耘時間（試験時間）は、高速条
件で59分46秒、低速条件で1時間52分43秒であった。 2. 試験終了直後に行った被験者からのヒアリン グでは、高速条件においては目の疲れと、試験半 ば過きころから眠くなったことが訴えられたが、 そう強いものではなかった。全身の疲労感の訴え はなかった。低速条件では終了後に「疲れた」と 応答した。とくに腰のたるさと、後頭部の疲れか 訴えられた。また、試駼途中で一時眠くなったか、 後半は目が覚めたと回答された。

3. 経過観察において、高速条件ではあくびはみ られなかったか、低速条件では試験開始後20〜30 分にかけてと、60分前後の時点でトラクター操縦 中のあくひが断続的に観察された。

4. 筋電図では、高速・低速条件ともにトラクタ 一の旋回に合わせて、右大腿部四頭筋と右総指伸 筋の一過的な筋電位の上昇かみられる。

5. 呼吸数でみると、高速条件では試験開始後 15 分くらいまでは25〜35回/分と多く、初期的な高 進状態を認めた。その後、25回/分内外のレベル に落ち着くが、35分過きからは再びバラッキが大 きくなるなかで、20回／分前後の安静值に近いレ ベルにまで低下する様子がられた。

低速条件では、最初の10分間で初期的な呼吸数 の上㫧がられたか、その後、15分から 30 分当た りにかけては毎分15回あたりと呼吸数の䫓著な低 下が認められる。また、60〜75分くらいまでにも 呼吸数の減少がられた。これらの現象は被験者 の眠けの訴えやあくびなととよく一致して起こっ ていた。

6. 上下方向の眼球運動記録から瞬目（ブリンキ ング）数の変動についてみると、高速条件では、 試験開始後26〜27分後の時点から顕著な減少か認 められた。26〜27分までの瞬目数は約 $5 \sim 8$ 回 $/ 10$ 秒（30〜50回/分程度）であったか、それ以降、 約3 7回 / 10秒（20〜 40回／分）のレベルに低下 した。

低速条件では、約7 8回/10秒（40５0回／分） のレベルにあり、高速条件と類似していた。しか し、15〜30分にかけてと60分過きの 2 回、断続的 だか、20回／10秒（120回／分）前後と、瞬目が群 発している様子を認めた。この群発瞬目は被験者 
か眠けに抗して頑張るときによくみられる現象で あるか、前後の状況から判断して、今回の例も眠 けに抗している場面と考えられる。

7. 左右方向の眼球運動記録から飛越運動（サッ ケード）の変動についてみると、高速条件では、 試験開始30分後あたりから、飛越運動回数の減少 か認められた。また、低速条件でも、15〜30分に かけてと60分過き当たりで、一過性の顕著な飛越 運動回数の低下があった。

これらの飛越運動回数の低下は被験者の眠けと 関連しているようであるか、耕耘の質確保や安全 運転のための視覚情報収集の質が悪くなっている ことが示されている。

8. 図2て高速条件における心拍数についてみると、 一様に低下する様子がみられ、単調状態を反映し た結果と解される。

9. 図2によって、呼吸、瞬目、サッケード回数な どをそれそれ5分間の平均値の変動によってみたと ころ、低速条件の結果か特徵的であった。とくに、 図中に口印をつけた 2 ヶ所では、本人の眠けの訴 えやあくびの発生とあわせて、呼吸の顕著な低下、 瞬目数の一過的な上昇、サッケード数の低下なと は同時に起こっていたことをみてとれる。

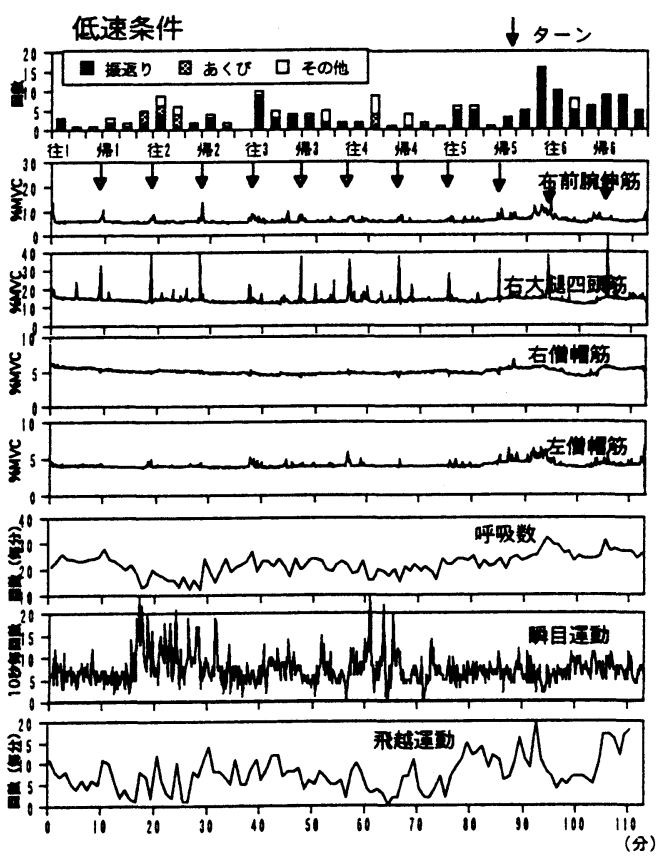

図1 低速条件における複合生理反応の変動

\section{4. 結論}

今回のような耕耘作業においては、作業の単調 性に起因する覚醒水準の低下と、長時間連続作業 による疲労現象とか重なって起こることが示唆さ れた。このうち、作業の単調性による覚醒水準の 低下現象の指標として、呼吸数、瞬目及ひ飛越運 動の連続测定と、タイムスタティによる作業状況 ならひにあくひなとの副次動作の同時分析が有効 であることが確認された。

大型宸業機械の長時間操縦にもとつく生体負担 の指標を明らかにしていくためには、今後、生理 指標ことの特徵記述にととまらず、(1)操椎行動と 生理指標との関連、とくに安全や運転の質（まっ すくに耕耘する、一定の深さで耕耘する、ほか） なとに代表される操縦パフォーマンスと覚醒水準 の低下や疲労状態との関連の解明、(2)複合生理反 応の相互の関連分析分析、とくにフェース別の相 関分析が期待される、(3)覚醒水準の低下や作業者 のへばりにいきつくブロセスの分析、などが必要 である。
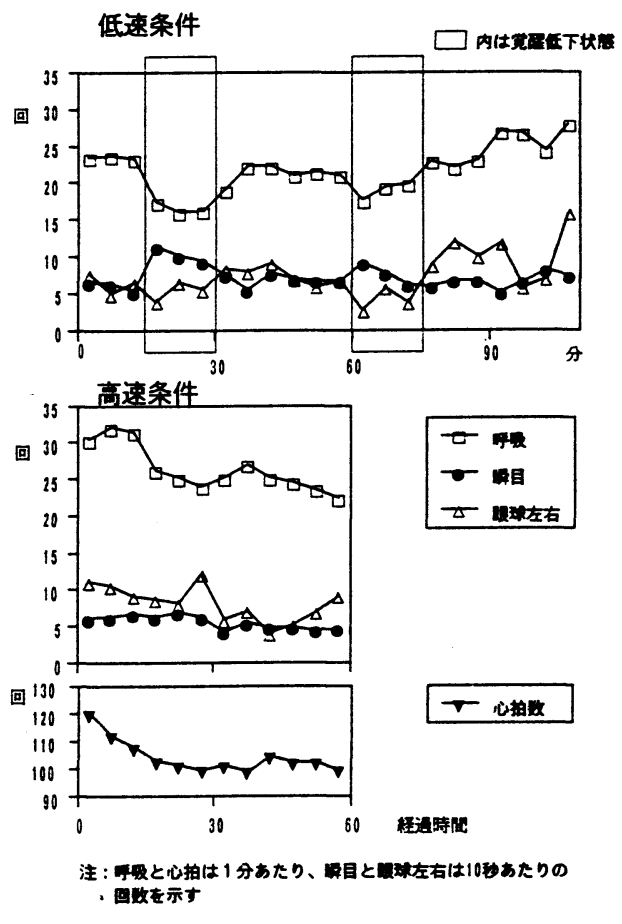

図2 複合生理反応の 5 分間の平均值の変動

【謝辞】本研究は、㖘水省「未来型軽労化農業技術確立のための基盤技術開発に関する総合研究」の一 環で行われ、北陸農業試験場小林恭室長、大黒正道研究員らとの共同実験の成果である。 